\title{
HYDROGEL CHANGES THE AIR-WATER RATIO OF PLANT SUBSTRATES
}

\author{
Eduarda Demari Avrella ${ }^{1 *}$, Luciana Pinto Paim², Aquélis Armiliato Emer ${ }^{3}$, Orlando Sílvio Caires Neves ${ }^{4}$, Gilmar \\ Schafer ${ }^{5}$, Claudimar Sidnei Fior $^{6}$

\begin{abstract}
${ }^{1}$ Universidade Federal do Rio Grande do Sul, Faculdade de Agronomia, Departamento de Horticultura e Silvicultura, Porto Alegre, Rio Grande do Sul, Brasil - dudademari@hotmail.com

${ }^{2}$ Universidade Federal do Rio Grande do Sul, Faculdade de Agronomia, Departamento de Horticultura e Silvicultura, Porto Alegre, Rio Grande do Sul, Brasil - lucianappaim@bol.com.br

${ }^{3}$ Universidade Federal do Rio Grande do Sul, Faculdade de Agronomia, Departamento de Horticultura e Silvicultura, Porto Alegre, Rio Grande do Sul, Brasil - aquelis_emer@hotmail.com

${ }^{4}$ Universidade Federal da Bahia, Campus Anísio Teixeira, Vitória da Conquista, Bahia, Brasil - orlandosilvio@ ufba.br

${ }_{5}^{5}$ Universidade Federal do Rio Grande do Sul, Faculdade de Agronomia, Departamento de Horticultura e Silvicultura, Porto Alegre, Rio Grande do Sul, Brasil - schafer@ufrgs.br

${ }^{6}$ Universidade Federal do Rio Grande do Sul, Faculdade de Agronomia, Departamento de Horticultura e Silvicultura, Porto Alegre, Rio Grande do Sul, Brasil - csfior@ufrgs.br
\end{abstract}

Received for publication: 20/09/2020 - Accepted for publication: 28/02/2021

\begin{abstract}
Resumo
Hidrogel altera a relação ar-água de substratos para plantas. A utilização de técnicas adequadas para otimizar a disponibilidade de água nos substratos é fundamental para a formação de mudas de qualidade. Portanto, o objetivo foi avaliar a influência do condicionamento físico do substrato por meio do uso de hidrogel. Os tratamentos consistiram do tratamento controle (sem adição de hidrogel) e três doses de hidrogel $(2,4$ e $6 \mathrm{~g} \mathrm{~L}$ ${ }^{1}$ de substrato) adicionados aos componentes casca de arroz carbonizada, areia regular média e turfa Sphagnum, de forma isolada, e em uma mistura composta por $50 \%$ de casca de arroz carbonizada e $50 \%$ de turfa (proporções volumétricas). O delineamento experimental foi inteiramente casualizado, e os substratos foram submetidos à caracterização física a $0,10,50$ e $100 \mathrm{hPa}$, por meio de funis de tensão, determinando-se porosidade total, espaço de aeração, água disponível, água remanescente e capacidade de retenção de água. Os resultados mostraram que o uso desse condicionador até $4 \mathrm{~g} \mathrm{~L}^{-1}$, em geral, aumentou a porosidade total e diminuiu o espaço aéreo. Houve aumento da água disponível e remanescente, principalmente para substratos com baixa capacidade de retenção de água (casca de arroz carbonizada e areia). Assim, o uso do hidrogel possibilita aumentar o intervalo entre as irrigações, resultando em melhorias significativas no sistema de produção.
\end{abstract}

Palavras-chave: água disponível; casca de arroz carbonizada; turfa de Sphagnum; polímero retentor de água.

\section{Abstract}

The use of appropriate techniques to optimize water availability in substrates is essential for the formation of quality seedlings. Therefore, the objective was to evaluate the influence of substrate physical conditioning through the use of hydrogel. The treatments consisted of the control treatment (without the addition of hydrogel) and three doses of hydrogel (2, 4 and $6 \mathrm{~g} \mathrm{~L}-1$ of substrate) added to components carbonized rice husk, average regular sand and Sphagnum peat isolated, and in a mixture composed of 50\% of carbonized rice husk and 50\% of peat (volumetric proportions). A completely randomized design was used, and the substrates were subjected to physical characterization at $0,10,50$ and $100 \mathrm{hPa}$, using tension funnels, determining total porosity, aeration space, available water, remaining water and water holding capacity. The results showed that the use of this conditioner up to $4 \mathrm{~g} \mathrm{~L}^{-1}$, generally, increased total porosity and decreased air space. There was an increase in available water and remaining water, especially for substrates with low water holding capacity (carbonized rice husk and sand). Thus, the use of hydrogel makes it possible to increase the period between irrigations, resulting in significant improvements in the production system.

Keywords: available water; carbonized rice husk; Sphagnum peat; water-retaining polymer.

\section{INTRODUCTION}

The seedling production aims to obtain quality seedlings for different purposes (AZEVEDO et al., 2019) because the final performance of the plants in the field depends on the quality of the seedlings produced (NAVROSKI et al., 2016b). The superiority in relation to seedling quality can be achieved using appropriate techniques, some are based on substrate properties, mainly physical and chemical characteristics (SILVA et al., 2014; NAVROSKI et al., 2015a).

According to Fermino and Kampf (2012), the substrate is the growth medium used in growing in containers, formed by solid particles and pores. Solid particles, of mineral, organic or synthetic origin can vary widely in physical aspects such as appearance, shape, size, and specific mass. 
With the advancement of container cultivation, there was a need to use substrates with different formulations and characteristics, which the physical and chemical characteristics are the most important (SCHAFER et al., 2015). Among the requirements, a substrate must have good water retention, high porosity, high structure stability and resistance to decomposition, absence of pathogens and propagules of unwanted plants, proper $\mathrm{pH}$, and availability of purchase and transportation (K̈̈MPF, 2005).

In this context, the use of substrates with adequate levels of water availability and aeration is of fundamental importance for the formation of quality seedlings, since the increasing pursuit of productivity and success in crop production are closely related to an adequate water supply in any plant production system. In view of this, there is a need for studies concerning the improvement of substrate water conditions, which can be achieved with the use of conditioners, such as water-retaining polymers.

Water-retaining polymers, also known as a hydrogel polymer, has been widely used in agriculture, especially in forest plantations (FERREIRA et al., 2014). Its main characteristics are the ability to absorb and hold large quantities of water, on the order of 10 to $1000 \mathrm{~g} \mathrm{~g}^{-1}$, maintaining the humidity of the soil for longer periods (MILANI et al., 2017). Research has shown the beneficial effect of water-retaining polymers incorporated into the substrate to produce seedlings of some species (BERNARDI et al., 2012; NAVROSKI et al., 2015ab). Although some studies show the advantages of its use, scarce information was found that clearly demonstrates which physical characteristics actually change with the addition of hydrogel to the components that compose the substrates. This information is fundamental to define the doses that will be incorporated in substrates with different physical characteristics since the new properties of the mixture will be directly related to these proportions. Therefore, the objective of this study was to evaluate the influence of substrate physical conditioning through the use of hydrogel.

\section{MATERIAL AND METHODS}

The study was conducted in the Horticulture and Forestry Department of the Agronomy Faculty of the Federal University of Rio Grande do Sul (UFRGS), in Porto Alegre, RS.

Among the physical characteristics related to substrate density, the bulk density (BD), and the dry density (DS) were evaluated through the self-compaction method (HOFFMANN, 1970). Total porosity (PT), air space (AS), available water (AW), remaining water (RW), and the water holding capacity were evaluated in the Laboratory of substrate analysis of the Faculty of Agronomy of UFRGS at 0, 10, 50, and $100 \mathrm{hPa}$, using tension funnels according to the principles of De Boodt and Verdonck (1972).

As stated by the manufacturer, the water-retaining polymer (hydrogel) used was a commercial polymer (Stockosorb ${ }^{\circledR}$ ) described as a potassium polyacrylate copolymer $\left(\mathrm{K}_{2} \mathrm{~S}_{2} \mathrm{O}_{8}\right)$, insoluble in water and free of acrylamide. Also, the product has particles of $0.1-0.9 \mathrm{~mm}$, mass density of 580 to $800 \mathrm{~g} \mathrm{~L}^{-1}$, cation exchange capacity of $3100 \mathrm{mmol} \mathrm{dm}^{-3}$, and water holding capacity of $180 \%$.

The treatments consisted of the control treatment (without the addition of hydrogel) and three doses of hydrogel (2, 4 and $6 \mathrm{~g} \mathrm{~L}^{-1}$ of substrate) added to components: carbonized rice husk (CRH), average regular sand and Sphagnum peat isolated, and in a mixture composed of $50 \%$ of carbonized rice husk and $50 \%$ of peat (volumetric proportions). Each hydrogel dose was hydrated with $180 \mathrm{~mL}$ of deionized water for each liter of the substrate. Subsequently, the hydrated hydrogel was manually mixed to the substrates, which were previously dried in a forced-air oven at $50{ }^{\circ} \mathrm{C}$ for 24 hours.

The treatments were arranged in a completely randomized design with four substrate compositions, four hydrogel doses, and five replications. Each substrate was analyzed individually. Data were submitted to analysis of variance (ANOVA), followed by a comparison of means using the LSD test (Least Significant Difference) at $5 \%$ of probability of error using the CoStat 6.4 software. For total porosity data of carbonized rice husk, KruskalWallis nonparametric analysis was performed because the data did not fulfill the assumptions of variance analysis.

In parallel with laboratory analysis, another experiment was conducted in a greenhouse to verify the water potential in the substrates when different hydrogel doses were added. Thus, a moisture control device was used on the substrate, of Hidrosense (Irrigás - MRI) company, which works with pressurized gas in the pores of the porous ceramic capsule and maintains a balance with the substrate by the principle of capillarity. The equipment consists of a digital measuring center and sensors installed in the monitored area. The sensors are connected to the measuring center by microtubes called measurement extensions, and the remote reading of the sensors is pneumatically taken by collecting an average sample of the substrate water tension (humidity).

After mixing the hydrogel with the substrates, one with a high water holding capacity (Sphagnum peat), and the other with a low water holding capacity (sand), the mixtures were placed in $1.7 \mathrm{~L}$ ( $20 \mathrm{~cm}$ high) containers and soaked for 72 hours. After saturation, the sensors were inserted into the center of the container and the set was weighed. Weekly, water loss monitoring was performed by weighing the vessels and at the end of the tests, the 
substrates were dried in a forced-air oven at $50{ }^{\circ} \mathrm{C}$ to constant weight to verify the remaining water content in the materials.

\section{RESULTS}

The analysis of the physical characteristics showed that the bulk density presented values of 395.60; $1,804.75 ; 356.22$, and $387.95 \mathrm{~kg} \mathrm{~m}^{-3}$ for Sphagnum peat, sand, carbonized rice husk and the mixture of Sphagnum peat and carbonized rice husk (1:1 v/v), respectively. While for dry density, the values were 98.22; 1,599.96; 129.84, and 114.03, respectively.

For total porosity, it was found that the carbonized rice husk showed a value of $81.44 \%$, while peat and the $\mathrm{CRH}+$ peat mixture obtained much higher values $(99.48 \%$ and $96.86 \%$, respectively). However, the sand presented the lowest value $(41.35 \%)$. About the air space, there was a variation of 8.09 to $63.91 \%$, in which the carbonized rice husk had the highest average value, and sand the lowest value (Table 1).

For available water, the carbonized rice husk had an extremely low value $(6 \%)$, and for remaining water the highest value was obtained for peat $(30.82 \%)$ (Table 1$)$.

Table 1. Mean and standard deviation of physical characteristics of the components of Sphagnum peat, sand, carbonized rice husk and the mixture of Sphagnum peat and carbonized rice husk $(1: 1 \mathrm{v} / \mathrm{v})$.

Tabela 1. Média e desvio padrão das características físicas dos componentes turfa de Sphagnum, areia, casca de arroz carbonizada e da mistura de turfa de Sphagnum e casca de arroz carbonizada (1:1 v/v).

\begin{tabular}{ccccc}
\hline & \multicolumn{5}{c}{ Substrates } \\
\cline { 2 - 5 } Properties & Peat & Sand & CRH & CRH + peat \\
\cline { 2 - 5 } BD $\left(\mathrm{kg} \mathrm{m}^{-3}\right)$ & $395.60 \pm 6.37$ & $1,804.75 \pm 14.76$ & $356.22 \pm 25.25$ & $387.95 \pm 9.72$ \\
DD $\left(\mathrm{kg} \mathrm{m}^{-3}\right)$ & $98.22 \pm 1.77$ & $1,599.96 \pm 9.21$ & $129.84 \pm 2.57$ & $114.03 \pm 2.86$ \\
CH $(\%)$ & $75.17 \pm 0.19$ & $12.19 \pm 0.22$ & $63.44 \pm 2.03$ & $70.61 \pm 0.35$ \\
TP $(\%)$ & $99.48 \pm 0.40$ & $41.35 \pm 0.89$ & $81.44 \pm 5.57$ & $96.86 \pm 1.51$ \\
AS $(\%)$ & $32.39 \pm 0.95$ & $8.09 \pm 0.96$ & $63.91 \pm 4.76$ & $40.37 \pm 3.81$ \\
AW $(\%)$ & $36.27 \pm 0.56$ & $27.89 \pm 0.39$ & $6.01 \pm 1.74$ & $35.83 \pm 2.55$ \\
RW $(\%)$ & $30.82 \pm 0.26$ & $5.37 \pm 0.34$ & $11.52 \pm 1.71$ & $20.65 \pm 0.96$ \\
\hline
\end{tabular}

$\mathrm{BD}=$ bulk density; $\mathrm{DD}=$ dry density; $\mathrm{CH}=$ current humidity; $\mathrm{TP}=$ total porosity; $\mathrm{AS}=$ air space; $\mathrm{AW}=$ available water; $\mathrm{RW}=$ remaining water; $\mathrm{CRH}=$ carbonized rice husk $\mathrm{CRH}+$ peat $=50 \%$ carbonized rice husk $+50 \%$ Sphagnum peat $(\mathrm{v} / \mathrm{v})$.

\section{Changes in substrate properties as a result of hydrogel presence}

The addition of hydrogel to substrates showed a significant effect for all evaluated physical characteristics, except for total porosity in peat. There was a decrease in the dry density of all substrates with the addition of hydrogel. In the absence of the hydrogel, the averages for peat, sand, carbonized rice husk and the mixture between peat and carbonized rice husk in 1:1 (v/v) proportion were $98.22 ; 1,599.96 ; 129.84$ and 114.03 $\mathrm{kg} \mathrm{m}^{-3}$, respectively. With the addition of the different hydrogel doses, there was an average reduction of 14.3, $20.7,5.7$ and $8.1 \%$, respectively.

In relation to total porosity, an increase was obtained with the use of hydrogel for sand, carbonized rice husk and the mixture of peat and carbonized rice husk (1:1 v/v) (Figure 1A). The $4 \mathrm{~g} \mathrm{~L}^{-1}$ dose provided higher values for this variable with the exception of sand, all substrates obtained values above $85 \%$, which is a range considered adequate by De Boodt and Verdonck (1972) for most crops. However, with the addition of the hydrogel, the total porosity of the sand increased considerably, reaching approximately $76 \%$ of porosity at a concentration of $4 \mathrm{~g} \mathrm{~L}^{-1}$. 

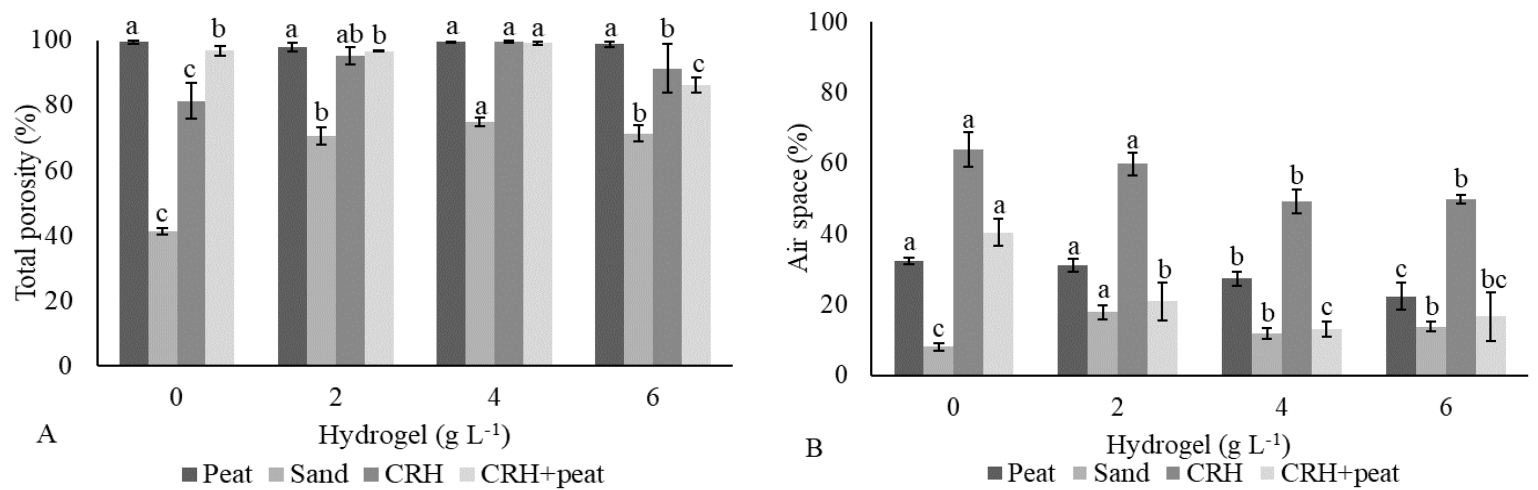

Figure 1. Mean and standard deviation of total porosity (A) and air space (B) of the substrates Sphagnum peat, carbonized rice husk $(\mathrm{CRH})$, sand and the mixture of carbonized rice husk and peat $(1: 1 \mathrm{v} / \mathrm{v})$, plus the hydrogel doses. Same lowercase letter between hydrogel doses for each substrate, do not show statistical difference by the LSD test (Least Significant Difference).

Figura 1. Média e desvio padrão da porosidade total (A) e espaço de aeração (B) dos substratos turfa de Sphagnum, casca de arroz carbonizada (CRH), areia e uma mistura de casca de arroz carbonizada e turfa (1: $1 \mathrm{v} / \mathrm{v})$, acrescidos de doses de polímero hidroretentor. Letras minúsculas entre as doses de hidrogel para cada substrato, não apresentam diferença estatística pelo teste LSD (Least Significant Difference).

About the air space, for sand there was an increase when the hydrogel was added to the medium. Nevertheless, for peat, carbonized rice husk and their mixture, there was a decrease as the hydrogel dose increased (Figure 1B).

Concerning the parameters related to water availability, the available water decreased as the hydrogel concentration increased for peat and sand, except for the dose of 2 in the sand. While for carbonized rice husk, there was an increase with the addition of hydrogel. Besides, the use of hydrogel in concentrations 2 and $4 \mathrm{~g} \mathrm{~L}^{-1}$ provided greater water availability for the substrate formulated from the mixture between carbonized rice husk and peat $(1: 1 \mathrm{v} / \mathrm{v})($ Figure $2 \mathrm{~A})$.

The percentage of remaining water increased in proportion to the increase in hydrogel concentrations for peat, sand, and the mixture of carbonized rice husk and peat (1:1 v/v) (Figure 2B).
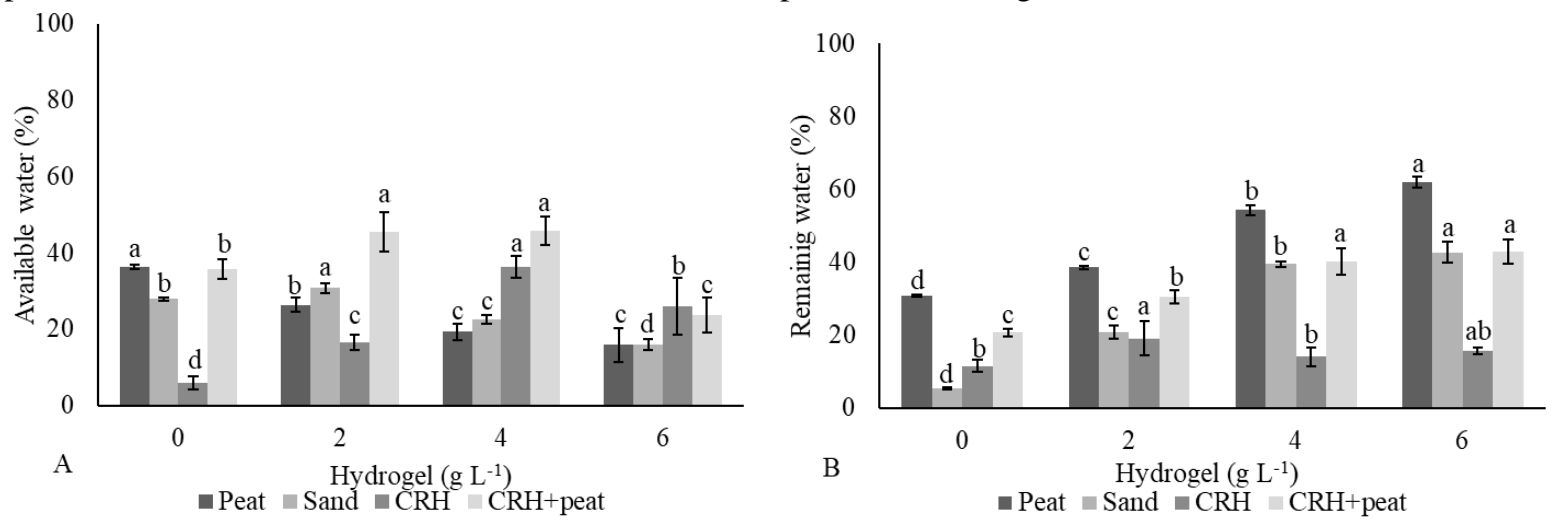

Figure 2. Mean and standard deviation of available water (A) and remaining water (B) of the substrates Sphagnum peat, carbonized rice husk (CRH), sand and the mixture of carbonized rice husk and peat (1:1 v/v), plus the hydrogel doses. Same lowercase letter between hydrogel doses for each substrate, do not show statistical difference by the LSD test (Least Significant Difference).

Figura 2. Média e desvio padrão da água disponível (A) e água remanescente (B) dos substratos turfa de Sphagnum, casca de arroz carbonizada (CRH), areia e uma mistura de casca de arroz carbonizada e turfa $(1: 1 \mathrm{v} / \mathrm{v})$, acrescidos de doses de polímero hidroretentor. Letras minúsculas entre as doses de hidrogel para cada substrato, não apresentam diferença estatística pelo teste LSD (Least Significant Difference). (Figure 3).

For water holding capacity, except for $\mathrm{CRH}$, there was an increase as hydrogel concentrations increased

From the substrate water potential monitoring data, it was found a greater loss of substrate moisture in the absence of hydrogel, which means that over the period of the experiment, with average temperature of $31.7^{\circ} \mathrm{C}$ and relative humidity of $49.2 \%$, the hydrogel enabled greater moisture retention. However, after 15 days of 
monitoring, the water potential of the medium decreased when in the absence of hydrogel, presenting more negative values than those obtained by the standard deviation of the mean of the treatments with the use of the concentrations of 2, 4 and $6 \mathrm{~g} \mathrm{~L}^{-1}$. Thus, it was observed that the use of the hydrogel allowed the water potential to remain stable during the conduction period of this experiment (Figure 4).
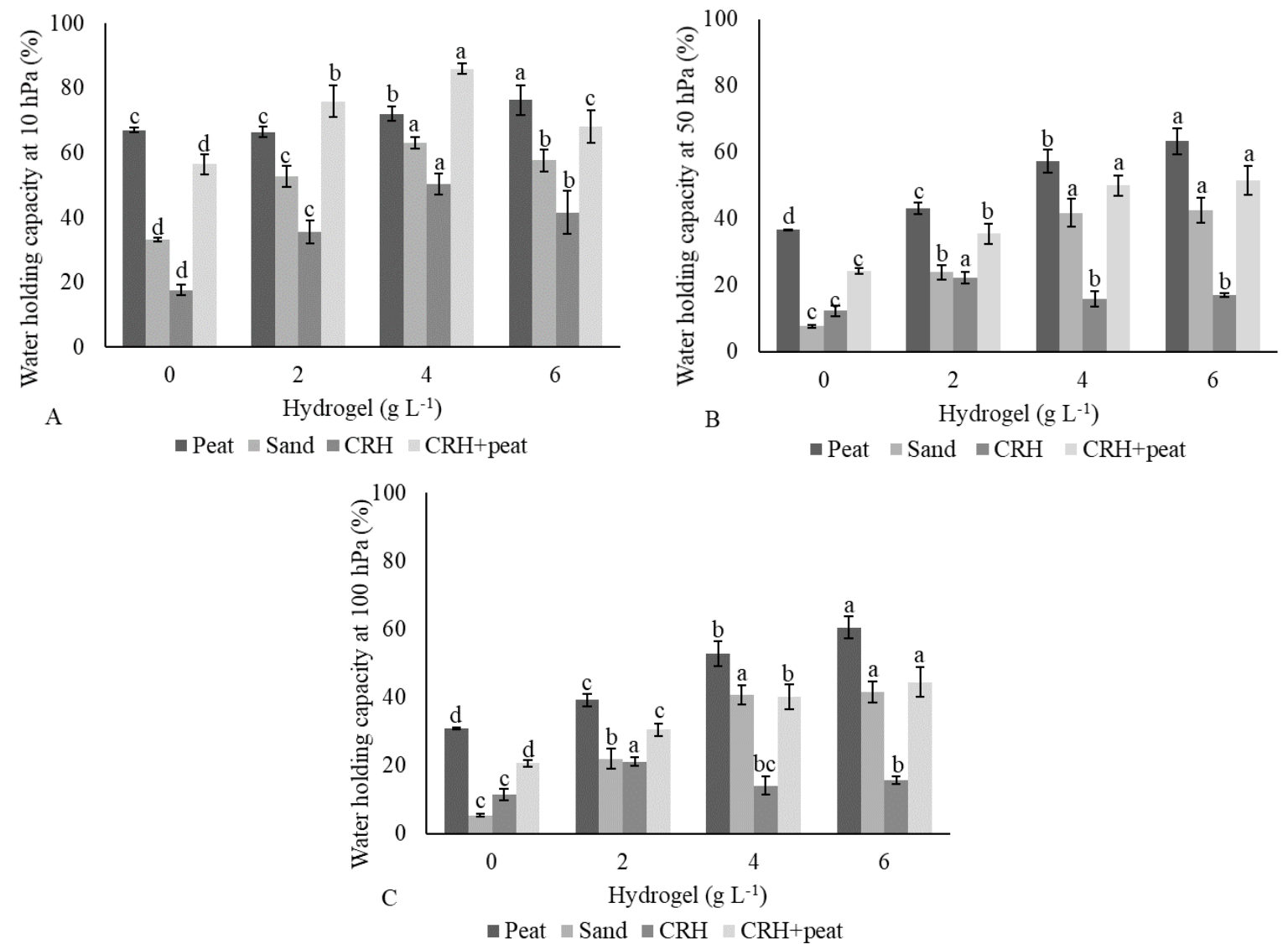

Figure 3. Mean and standard deviation of water holding capacity at 10 (A), 50 (B) and $100 \mathrm{hPa}(\mathrm{C})$ of tension of the substrates Sphagnum peat, carbonized rice husk (CRH), sand and the mixture of carbonized rice husk and peat (1:1 v/v), plus the hydrogel doses. Same lowercase letter between hydrogel doses for each substrate, do not show statistical difference by the LSD test (Least Significant Difference).

Figura 3. Média e desvio padrão da capacidade de retenção de água a 10 (A), 50 (B) e $100 \mathrm{hPa}$ (C) de tensão dos substratos turfa de Sphagnum, casca de arroz carbonizada (CRH), areia e uma mistura de casca de arroz carbonizada e turfa $(1: 1 \mathrm{v} / \mathrm{v})$, acrescidos de doses de polímero hidroretentor. Letras minúsculas entre as doses de hidrogel para cada substrato, não apresentam diferença estatística pelo teste LSD (Least Significant Difference).
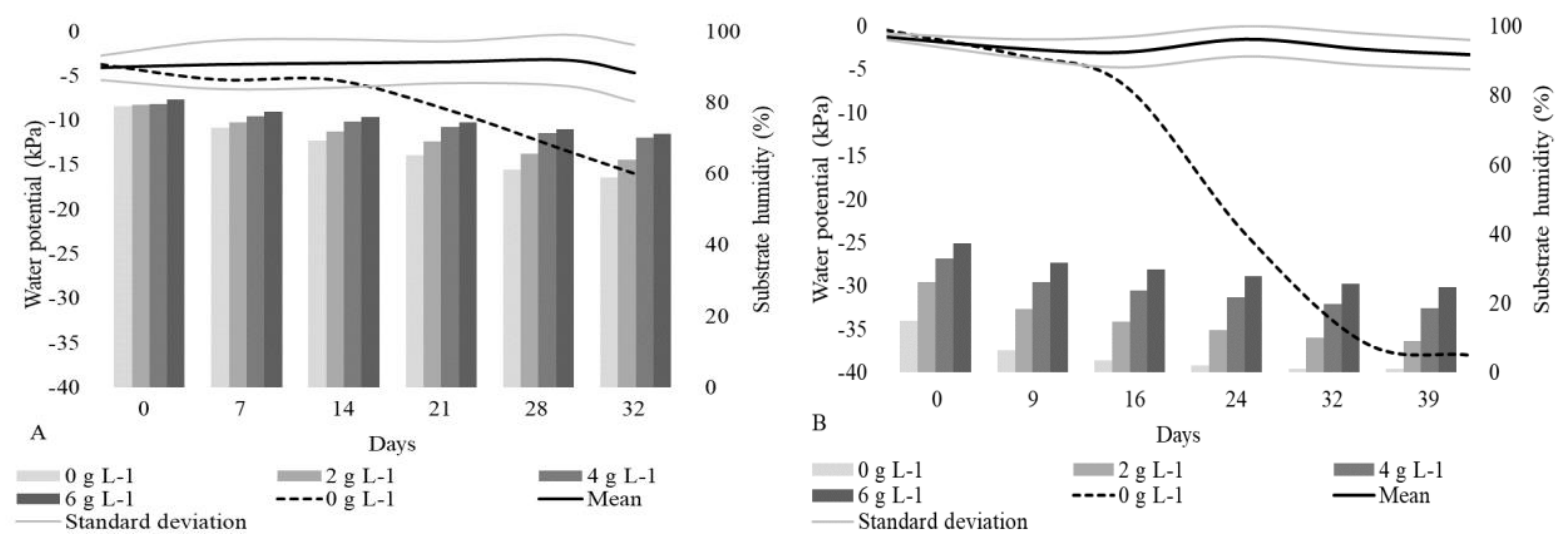

Figure 4. Water potential of the substrates Sphagnum peat (A) and sand (B), plus the hydrogel doses. Bars correspond to substrate humidity $(\%)$ and lines correspond to water potential $(\mathrm{kPa})$, where the dotted 
line refers to the water potential of substrates in the absence of hydrogel and the continuous lines to the water potentials in the presence.

Figura 4. Potencial hídrico nos substratos turfa de Sphagnum (A) e areia (B), acrescidos de doses de polímero hidroretentor. Barras correspondem a umidade do substrato (\%) e linhas correspondem ao potencial de água $(\mathrm{kPa})$, onde a linha pontilhada se refere ao potencial de água dos substratos na ausência e linha contínua na presença de polímero hidroretentor.

\section{DISCUSSION}

Based on the recommendations of Kämpf (2005), the physical characterization analysis demonstrated that for the dry density (Table 1) the substrates peat, carbonized rice husk and their mixture in a proportion of 1:1 (v/v) can be used for plant propagation in small containers, as tray cells, because the values should vary from 100 to $300 \mathrm{~kg} \mathrm{~m}^{-3}$. However, the sand has high density values and is not recommended for use in containers as a single material, is indicated as a component in mixtures.

Knowing the value of density enables various applications, serving as a parameter for irrigation management, for nutrient analysis (with reference to sample mass), and also assists in container selection (FERMINO; KÄMPF, 2012). It is recommended to avoid extreme values since light substrates may lead to tipping of containers, which makes handling difficult, and provide little contact between the plant root system and the environment. On the other hand, very dense materials can hinder penetration and root development due to mechanical impedance (KÄMPF, 2005; FERMINO; KÄMPF, 2012). However, as regards sand, despite being an extremely dense material, it has low water holding capacity, which is beyond the recommendations on how to use containers according to their height, that would be up to $800 \mathrm{~kg} \mathrm{~m}^{-3}$, according to Kämpf (2005).

The increase in total porosity with hydrogel addiction occurs due to the change in the amount of substrate in the same sample volume. In other words, when the total porosity is determined a certain volume is used and mixing hydrated hydrogel, this same volume becomes integrated by the substrate plus the hydrated polymer. When the sample is dehydrated, instead of water, the pores remain. This fact was also observed by Navroski et al. (2016b) in which total porosity as risen for all substrates tested as the hydrogel concentration increased.

The decrease in air space by adding the hydrogel from the $4 \mathrm{~g} \mathrm{~L}^{-1}$ dose is due to the filling of macropores with the hydrated polymer, providing substrates with high water retention. The tension caused during macroporosity evaluation $(10 \mathrm{hPa})$ is not enough to remove the water absorbed by the hydrogel, so that the pores remain filled with hydrated polymer.

Substrate water availability data are important as they provide information on the volume of water available to plants within each tension range (FERMINO, 2014). De Boodt and Verdonck (1972) established tensions between 0 and $100 \mathrm{~cm}$ of water column $(0 \mathrm{a} 100 \mathrm{hPa})$ as essential values in substrate characterization. Thus, the tensions are classified as available water (volumetric water released between $10 \mathrm{hPa}$ and $100 \mathrm{hPa}$ ) and remaining water (volume of water remaining on the substrate after applying $100 \mathrm{hPa}$ of tension) (FERMINO, 2014). For available water, the carbonized rice husk presented extremely low value (6\%), which is related to a high percentage of macropores and consequently provide low water holding capacity and high drainage in this material. Therefore, Watthier et al. (2017) do not recommend the use of pure carbonized rice husk as a substrate for use in the production of seedlings, due to the low amount of available water.

According to Schafer et al. (2015), on substrates with low available water values, irrigation management must be efficient to avoid wasting water and, thus, it is recommended to increase the number of irrigations and decrease the volume applied to each irrigation. The addition of hydrogel provided improvements in water conditions (available water content), especially in the substrates with low water holding capacity. This result was evidenced by the significant increase in the available water values in the carbonized rice husk.

In the last 40 years, the hydrogels have been widely used to improve the water retention properties of culture media (NEETHU et al., 2018). However, the water retention capacity of hydrogels can be influenced by several factors, such as its physical and chemical composition, particle size, texture, $\mathrm{pH}$ and density, as well as the soluble salts present in the environment (AZEVEDO et al., 2019). This fact was observed by Navroski et al. (2016b) in that the behavior of the hydrogel vary according to the composition of the substrate used. In such a study the available water increased with the increase in the concentration of the hydro polymer for the commercial substrate and its mixture with carbonized rice husk, but remained stable or slightly decreased when the commercial substrate was mixed with vermiculite, or mixed with vermiculite and rice husk. A similar result was verified by Neres et al. (2019), testing the effect of the incorporation of hydrogel in different substrates on the rhizogenesis and quality of clonal seedlings of eucalyptus. In this study, the authors observed that the efficiency of the hydrogel for improving the quality of the rhizogenesis of mini-cuttings and seedling development depends on the physical and chemical characteristics of the substrates. 
The sand and the carbonized rice husk showed very low volumes of remaining water due to their low water storage capacity. However, in this study, even the lower concentration of hydrogel added to the sand mixture caused an increase in the water storage capacity.

The results of the increase in water holding capacity with increasing use of hydrogel agree with those found by Lopes et al. (2010), Navroski et al. (2015a), Navroski et al. (2015b), Felippe et al. (2016), Navroski et al. (2016a), Navroski et al. (2016b) and Azevedo et al. (2019). Thus, the hydrogel makes it possible to improve the physical characteristics of the substrate, especially those related to water retention, making it possible to decrease the amount of irrigation water (NAVROSKI et al., 2015b).

The addition of the remaining water content associated with the increased in water holding capacity when hydrogel is used in substrate composition can be an important alternative in the hardening phase in the production of seedlings of forest species as this practice progressively increases the time between irrigations. At this stage, a greater physiological effort of the seedling for water absorption is sought, what according to Sharma et al. (2019), triggers in the plant the accumulation of compatible solutes to maintain cell turgor, making them more resistant to lack of water.

The high values of water holding capacity of the substrates with the addition of the hydrogel indicates that the polymer can store water and make it available to plants in situations of low water availability. According to Taiz et al. (2017), the water deficit affects basic physiological processes, including stomatal closure induced by the production of abscisic acid, which consequently decreases gas exchange and inhibits photosynthesis. When plant cells are subjected to water deficit, cell dehydration occurs and ions become more concentrated, which can become cytotoxic. There are also effects on leaf abscission, destabilization of membranes and proteins, and cell death, among others.

From the substrate water potential monitoring data, it was observed that the use of the hydrogel allowed the water potential to remain stable during the conduction period of this experiment. From these results it is possible to infer that water-retaining polymers can gradually supply the water needs of plants, ensuring an adequate water supply for longer periods (MILANI et al., 2017).

The use of hydrogel added to substrates during the production of Mimosa scabrella Benth. seedlings promoted a positive effect on the growth of these plants, mainly due to the greater water retention of the substrate, also allowing greater absorption of nutrients (KONZEN et al., 2017). Similarly, in seedlings of Eucalyptus benthamii Maiden et Cambage, the use of hydrogel provides a delay in the symptoms of water deficit, presenting greater efficiency when irrigation is performed less frequently (FELIPPE et al., 2016). This confirms the hypothesis that with the addition of the hydrogel, the substrate will make water available to plants under reduced water availability.

In general, it is difficult to obtain a substrate that meets all the ideal characteristics for a particular crop at each stage of development. Therefore, alternatives that provide improvements are essential, especially in the substrate water conditions, which according to Navroski et al. (2015a), can be achieved with the use of conditioners, such as hydrogel, which has direct effects on plant development by decreasing losses of irrigation water and nutrient leaching. The results of the present study show that the use of this conditioner up to $4 \mathrm{~g} \mathrm{~L}^{-1}$ increased total porosity and decreased air space. There was an increase in available water and remaining water, especially for substrates with low water holding capacity.

The knowledge about the balance between porous space and water availability combined with the container used is crucial to make decisions on the use of techniques that enable improvements in substrate properties. Also, in most cases, irrigation in nurseries still disregards the use of methods that can reduce water consumption. It is the case of correctly managing the systems of cultivation or production of seedlings taking into account the interaction between water demand, substrate composition, water regime, and cultivation containers.

In this context, the use of hydrogel added to substrate components becomes an important alternative because it mitigates the effects of problems caused by improper irrigation management. Furthermore, can also control the release of fertilizers and nutrients, becoming an input of great importance in the production of seedlings (NIRMALA; GUVVALI, 2019; ZAINAL et al., 2021). However, further research is needed to confirm the favorable effect of hydrogel on plant growth and development, as well as for the excess of irrigation, because the effects can vary according to the chemical and physical composition of the substrate, the irrigation management adopted and the species cultivated.

\section{CONCLUSIONS}

In this study, we concluded that:

- The use of hydrogel as a conditioner of substrate properties may result in significant improvements in the production system, as it positively alters the physical characteristics (available water, remaining water and water holding capacity) of materials widely used in substrate composition for various cultures; 
- The possibility of increasing the period between irrigations in substrates with hydrogel addition, due to the increase of available and remaining water.

\section{ACKNOWLEDGEMENTS}

The authors thank the Coordenação de Aperfeiçoamento de Pessoal de Nível Superior (CAPES), the Conselho Nacional de Desenvolvimento Científico e Tecnológico (CNPq), the Fundação de Amparo à Pesquisa do Estado do Rio Grande do Sul (FAPERGS) laboratory technician Idenir José de Conto.

\section{REFERENCES}

AZEVEDO, G. T. O. S.; SOUZA, A. M.; AZEVEDO, G. B.; TEODORO, P. E.; SOUSA, J. R. L. Influence of fertilizer and hydrogel on physicalchemical attributes of substrate for seedling production. Bioscience Journal, Uberlândia, v. 35, n. 5, p. 1399 - 1407, 2019.

BERNARDI, M. R.; SPEROTTO JUNIOR, M.; DANIEL, O.; VITORINO, A. C. T. Crescimento de mudas de Corymbia citriodora em função do uso de hidrogel e adubação. Cerne, Lavras, v. 18, n. 1, p. 67 - 74, 2012.

DE BOODT, M.; VERDONCK, O. The physical properties of the substrates in horticulture. Acta Horticulturae, The Hague, v. 26, p. 37 - 44, 1972.

FELIPPE, D.; NAVROSKI, M. C.; SAMPIETRO, J.A.; FRIGOTTO, T.; ALBUQUERQUE, J.A.; MOTA, C. S.; PEREIRA, M. O. Efeito do hidrogel no crescimento de mudas de Eucalyptus benthamii submetidas a diferentes frequências de irrigação. Floresta, Curitiba, v. 46, n. p. 215 - 225, 2016.

FERMINO, M. H. Substratos: composição, caracterização e métodos de análise. Guaíba: Agrolivros, 2014,112 p.

FERMINO, M. H.; KÄMPF, A. N. Densidade de substratos dependendo dos métodos de análise e níveis de umidade. Horticultura Brasileira, Vitória da Conquista, v. 30, n. 1, p. 75 - 79, 2012.

FERREIRA, E. A.; SILVA, V. A.; SILVA, E. A.; SILVEIRA, H. R. O. Eficiência do hidrogel e respostas fisiológicas de mudas de cultivares apirênicas de citros sob défice hídrico. Pesquisa Agropecuária Tropical, Goiânia, v. 44, n. 2, p. 158 - 165, 2014.

HOFFMANN, G. Verbindliche methoden zur untersuchung von TKS und gartnerischen erden. Mitteilungen der VSLUFA, Darmstadt, v. 6, p. 129 - 153, 1970.

KÄMPF, A. N. Produção comercial de plantas ornamentais. Guaíba: Agrolivros, 2005, 256 p.

KONZEN, E. R.; NAVROSKI, M. C.; FRIEDERICHS, G.; FERRARI, L. H.; PEREIRA, M. O.; FELIPPE, D. The use of hydrogel combined with appropriate substrate and fertilizer improve quality and growth performance of Mimosa scabrella Benth. seedlings. Cerne, Lavras, v. 23, n. 4, p. 473-482, 2017.

LOPES, J. L. W.; SILVA, M. R.; SAAD, J. C. C.; ANGÉLICO, T. S. Uso do hidrogel na sobrevivência de mudas de Eucalyptus urograndis produzidas com diferentes substratos e manejos hídricos. Ciência Florestal, Santa Maria, v. 20, n. 2, p. 217 - 224, 2010.

MILANI, P.; FRANÇA, D.; BALIEIRO, A. G.; FAEZ, R. Polymers and its applications in agriculture. Polímeros, São Carlos, v. 27, n. 3, p. 256 - 266, 2017.

NAVROSKI, M. C.; ARAÚJO, M. M.; CUNHA, F. S.; BERGHETTI, Á. L. P.; PEREIRA, M. O. Redução da adubação e melhoria das características do substrato na produção de mudas de Eucalyptus dunnii. Ciência Florestal, Santa Maria, v. 26, n. 4, p. 1155 - 1165, 2016a.

NAVROSKI, M. C.; ARAÚJO, M. M.; FIOR, C. S.; CUNHA, F. S.; BERGHETTI, A. L. P.; PEREIRA, M. O. Uso de hidrogel possibilita redução da irrigação e melhora o crescimento inicial de mudas de Eucalyptus dunnii Maiden. Scientia Forestalis, Piracicaba, v. 43, n. 106, p. 467 - 476, 2015 b.

NAVROSKI, M. C.; ARAÚJO, M. M.; PEREIRA, M. O.; FIOR, C. S. Influência do hidrogel no crescimento e no teor de nutrientes das mudas de Eucalyptus dunnii. Floresta, Curitiba, v. 45, n. 2, p. 315 - 328, $2015 \mathrm{a}$.

NAVROSKI, M. C.; ARAÚJO, M. M.; REINIGER, L. R. S.; FIOR, C. S.; SCHAFER, G.; PEREIRA, M. O. Initial growth of seedlings of Eucalyptus dunnii Maiden as influenced by the addition of natural polymer and farming substrates. Revista Árvore, Viçosa, v. 40, n. 4, p. 627 - 637, 2016 b. 
NEETHU, T. M.; DUBEY, P. K.; KASWALA, A. R. Prospects and applications of hydrogel technology in agriculture. International Journal of Current Microbiology and Applied Sciences, Tamilnadu, v. 7, n. 5, p. 3155-3162, 2018.

NERES, Y. X. C.; AZEVEDO, G. T. O. S.; SOUZA, A. M.; AZEVEDO, G. B.; TEODORO, P. E. Effect of the hydrogel incorporation on different substrates on the rooting and quality of clonal Eucalyptus seedlings. Scientia Forestalis, Piracicaba, v. 47, n. 122, p. 336-345, 2019.

NIRMALA, A.; GUVVALI, T. Hydrogel/superabsorbent polymer for water and nutrient management in horticultural crops-review. International Journal of Chemical Studies, New Delhi, v. 7, n. 5, p. 787-795, 2019.

SCHAFER, G.; SOUZA, P. V. D.; FIOR, C. S. Um panorama das propriedades físicas e químicas de substratos utilizados em horticultura no sul do Brasil. Ornamental Horticulture, Campinas, v. 21, n. 3, p. 299 - $306,2015$.

SHARMA, A.; SHAHZAD, B.; KUMAR, V.; KOHLI, S. K.; SIDHU, G. P. S.; BALI, A. S.; HANDA, N.; KAPOOR, D. R. B.; ZHENG, B. Phytohormones regulate accumulation of osmolytes under abiotic stress. Biomolecules, Basel, v. 9, p. 1 - 36, 2019.

SILVA, R. F.; EITELWEIN, M. T.; CHERUBIN, M. R.; FABBRIS, C.; WEIRICH, S.; PINHEIRO, R. R. Produção de mudas de Eucalyptus grandis em substratos orgânicos alternativos. Ciência Florestal, Santa Maria, v. 24, n. 3, p. $609-616,2014$.

TAIZ, L.; ZEIGER, E.; MOLLER, I. M.; MURPHY, A. Fisiologia e desenvolvimento vegetal. Porto Alegre: Artmed, 6 ed. 2017, 888 p.

WATTHIER, M.; SILVA, M. A. S.; SCHWENGBER, J. E.; FERMINO, M. H.; CUSTÓDIO, T. V. Production of lettuce seedlings in substrates with tung compost, carbonized rice husk and earthworm humus. Horticultura Brasileira, Vitória da Conquista, v. 35, n. 2, p. 174 - 179, 2017.

ZAINAL, S. H.; MOHD, N. H.; SUHAILI, N.; ANUAR, F. H.; LAZIM, A. M.; OTHAMAN, R. Preparation of celulose-based hydrogel: a review. Journal of Materials Research and Technology, São Paulo, v. 10, p. 935952, 2021. 